\title{
KURIKULUM INTERNASIONAL PENDIDIKAN
}

\section{Nirsantono Hasnul}

\begin{abstract}
The purposes of this research were to compare the curriculum of Special Education (PLB) Faculty of Education (FIP), State University of Jakarta (UNJ) with special education curriculum of HNU Programs, China, and to obtain an international curriculum for majors sujects in PLB FIP UNJ in 2010. The research which was conducted at FIP and HNU employed descriptive method and the data were collected using observation and interviews. The comparison between the two universities indicated that the special education curriculum of FIP UNJ is more comprehensive and student's competency to be achieved consists of five areas: personality development, knowledge and skills, working skills, working behaviors, and social life. The research findings indicate that the international curriculum of Special Education Programs (PLB), FIP, UNJ, can be used for overseas students particularly China who are interested in special education.
\end{abstract}

Key words: special education, curriculum, competence

\begin{abstract}
Abstrak
Tujuan penelitian ini adalah untuk membandingkan kurikulum pendidikan luar biasa Fakultas Ilmu Pendidikan Universitas Negeri Jakarta dengan kurikulum pendidikan luar biasa dari program HNU di Cina dan untuk memperoleh suatu kurikulum internasional tahun 2010 untuk mata kuliah-mata kuliah utama di PLB FIP UNJ. Penelitian yang dilakukan di FIP dan HNU menggunakan metode deskriptif dan data dikumpulkan dengan menggunakan pengamatan dan wawancara. Perbandingan di antara dua universitas menunjukkan bahwa kurikulum pendidikan luar biasa FIP UNJ lebih komprehensif dan kemampuan mahasiswa yang harus dicapai meliputi lima bidang: pengembangan kepribadian, kemampuan dan keterampilan, keterampilan bekerja, perilaku kerja, dan kehidupan sosial. Hasil penelitian menunjukkan kurikulum internasional PLB FIP UNJ dapat dipergunakan untuk mahasiswamahasiswa asing khususnya mahasiswa Cina yang tertarik dalam pendidikan luar biasa.
\end{abstract}

Kata kunci: pendidikan luar biasa, kurikulum, kompetensi

\section{PENDAHULUAN}

Universitas Negeri Jakarta (UNJ) adalah salah satu lembaga pendidikan tempat menggali ilmu pengetahuan, teknologi, dan seni tertinggi. Dalam pengembangannya UNJ yang dahulu bernama Institut Keguruan Ilmu Pendidikan (IKIP) Jakarta, sudah mengarah menjadi suatu universitas yang berskala nasional dan menuju universitas yang berskala internasional.

Jurusan Pendidikan Luar Biasa (PLB) Fakultas Ilmu Pendidikan (FIP) UNJ sebagai bagian dari UNJ perlu meningkatkan diri dalam menjaga dan memelihara mutu akademik dan nonakademik. Salah satu untuk meningkatkan diri adalah dengan melihat ke jurusan PLB dari universitas yang berbeda agar dapat menganalisis kelebihan dan kekurangan dari jurusan.

Huazhong Normal University (HNU) yang berada di Wuhan, Propinsi Hubei, China adalah salah satu "IKIP" yang termasuk terbaik di China. Berbeda dengan UNJ yang berada di ibukota, HNU meskipun bukan di Beijing (ibukota) namun HNU memiliki akses yang mudah dicapai. Selain itu, HNU juga memiliki report yang bagus yaitu adanya kerjasama dengan beberapa universitas dunia seperti Kansas University (USA) dan universitas di Australia. Universitas dari Indonesia yang telah bekerjasama dengan $\mathrm{HNU}$ adalah Universitas Negeri Surabaya (UNESA) dan telah terjadi pengiriman dosen antardua universitas tersebut.

Pada tanggal 28 September 2010, UNJ juga telah menandatangani Memorandum of Understanding (MoU) dengan HNU dalam bidang akademik. Untuk itu, jurusan PLB juga termasuk di dalam MoU yaitu sebagai bagian dari jurusan yang berada di UNJ dan dapat memfollow up dengan berbagai aktivitas.

Atas dasar ini, maka Jurusan PLB FIP UNJ berkeinginan untuk mengadakan penelitian tentang perbandingan kurikulum PLB dalam rangka internasionalisasi jurusan PLB FIP UNJ. Langkah yang telah ditempuh adalah mengadakan kunjungan observasi 
dan wawancara serta mengirimkan seorang dosen jurusan untuk mengikuti screening program BATCH III yang diselenggarakan oleh Ditjen Pendidikan Tinggi (Ditjendikti). Setelah lulus seleksi maka diperbolehkan untuk mengikuti perkuliahan di HNU selama 3 bulan.

Berdasarkan latar belakang, maka dapat diidentifikasikan permasalahan sebagai berikut, (a) apa sajakah mata kuliah yang terdapat di jurusan PLB FIP UNJ? (b) bagaimana kurikulum jurusan PLB FIP UNJ dapat menjadi kurikulum internasional? (c) apa sajakah mata kuliah yang terdapat di jurusan PLB HNU China? (d) bagaimana gambaran umum HNU? dan (e) bagaimana kurikulum internasional PLB FIP UNJ?

Penelitian ini membatasi masalah pada kurikulum internasional jurusan Pendidikan Luar Biasa (PLB) FIP Universitas Negeri Jakarta (UNJ).

Berdasarkan pembatasan masalah maka dirumuskan masalah sebagai berikut, bagaimana kurikulum internasional jurusan Pendidikan Luar Biasa (PLB) FIP UNJ?

Mengacu pada rumusan masalah tersebut, tujuan penelitian ini ialah untuk mengetahui kurikulum internasional jurusan Pendidikan Luar Biasa (PLB) FIP UNJ. Hasil penelitian ini diharapkan bermanfaat untuk jurusan PLB FIP UNJ dalam: (a) membandingkan kurikulum HNU di China dengan UNJ agar dapat dianalisis kemungkinan double degree; (b) melalui studi banding jurusan PLB FIP UNJ dapat menyusun kurikulum internasionalnya; dan (c) meningkatkan ilmu pengetahuan dan wawasan dosen jurusan PLB FIP UNJ dalam bidang pendidikan luar biasa.

Berdasarkan latar belakang yang telah dikemukakan, pembahasan dalam penelitian ini diarahkan pada quality assurance serta penjajakan langkah ke depan dalam penyelenggaraan double degree

\section{KAJIAN PUSTAKA}

\section{Pengertian Kurikulum}

Kurikulum secara formal menurut wikipedia yaitu "a curriculum is the set of courses and their content offered at a school or university. As an idea curriculum stems from the latin word for race course, referring to the course of deeds and experience true which children growth to become mature adult". Makna ini memberikan gambaran bahwa kurikulum adalah seperangkat mata pelajaran dan isi dari mata pelajaran tersebut yang ditawarkan di sekolah atau universitas. Sebagai suatu ide, kurikulum berasal dari bahasa Latin yaitu race course.

Menurut Sudrajat (2009: 1), kurikulum merupa- kan bagian dari sistem pendidikan yang tidak bisa dipisahkan dengan komponen sistem lainnya. Tanpa kurikulum, suatu sistem pendidikan tidak dapat dikatakan sebagai sistem pendidikan yang sempurna. Kurikulum merupakan ruh (spirit) yang menjadi gerak dinamik suatu sistem pendidikan. Kurikulum juga meru-pakan sebuah ide vital yang menjadi landasan bagi terselenggaranya pendidikan yang baik. Bahkan, kurikulum seringkali menjadi tolok ukur bagi kualitas dan penyelenggaraan pendidikan. Baik buruknya kurikulum akan sangat menentukan terhadap baik buruknya kualitas output pendidikan, dalam hal ini, peserta didik.

Kerr dalam Infed (2000: 1) mendefinisikan kurikulum sebagai all the learning which is planned and guided by the school, whether it is carried on in groups or individually, inside or outside the school. Ini berarti bahwa semua yang dipelajari adalah dipelajari dan dibimbing oleh sekolah, apakah itu dibawakan dalam kelompok atau individu, di dalam atau di luar sekolah.

Menurut pandangan modern, kurikulum diartikan sebagai "segala upaya institusi" untuk merangsang mahasiswa belajar apakah di ruang kelas, di halaman, dan di luar sekolah. Pengertian seperti ini antara lain menurut Alberty dan Alberty (dalam Hasibuan, 2010) menyebutkan bahwa kurikulum adalah semua aktivitas yang disediakan untuk mahasiswa oleh sekolah. Berarti kurikulum sekolah harus dapat memotivasi mahasiswa yang disesuaikan dengan sarana dan prasarana pendukung supaya mahasiswa dapat belajar sesuai dengan tuntutan kurikulum.

Senada dengan pendapat Tyler sebagaimana yang dikutip oleh Tanner (1980) bahwa kurikulum adalah semua kegiatan pembelajaran mahasiswa yang direncanakan dan diarahkan oleh sekolah untuk mencapai tujuan pendidikan.

Pengertian-pengertian kurikulum modern yang dijelaskan oleh S. Nasution (1980) bahwa makna kurikulum tersebut tidak lagi hanya terbatas pada kegiatan-kegiatan formal seperti yang dilakukan di ruang kelas, tetapi makna kurikulum sudah meluas mencakup kegiatan-kegiatan belajar yang terjadi di halaman dan di luar sekolah. Berarti makna kurikulum mencakup keseluruhan kegiatan belajar peserta didik yang direncanakan oleh sekolah atau jurusan/ program studi sepanjang peserta didik masih terikat dengan lembaga pendidikan yang diikutinya.

Kurikulum modern menurut Alice Miel sebagaimana dikutip oleh S. Nasution (1980) yaitu mempertegas makna kurikulum mencakup keadaan gedung, suasana kampus, keinginan, keyakinan, 
pengetahuan, kecakapan, dan sikap orang-orang yang melayani dan dilayani di Perguruan Tinggi mulai dari peserta didik, masyarakat, para pendidik, pegawai dan pimpinan sampai pada pelayanan PT seperti office boy dan penjaga (SATPAM). Semua unsur-unsur tersebut memberikan pengaruh pada minat dan motivasi mahasiswa dalam belajar.

Menurut SK Mendiknas No. 232/U/2000 tentang Pedoman Penyusunan Kurikulum Pendidikan Tinggi dan Penilaian Hasil Belajar Peserta Didik, kurikulum adalah seperangkat rencana dan pengaturan mengenai isi maupun bahan kajian dan pelajaran serta cara penyampaian dan penilaiannya yang digunakan sebagai pedoman penyelenggaraan kegiatan belajar dan mengajar di perguruan tinggi.

Kurikulum memuat tentang pembelajaran yang harus diketahui oleh mahasiswa serta bagaimana cara mahasiswa mencapai tujuan pendidikan dan kompetensi lulusan. Kurikulum dikemas dalam bentuk yang mudah dikomunikasikan kepada berbagai pihak yang berkepentingan (stakeholders) di dalam institusi pendidikan, akuntabel, dan mudah diaplikasikan dalam praktik. Kurikulum harus responsif terhadap perubahan kebutuhan stakeholders akan lulusan program studi tersebut.

Kurikulum dapat berbasis kompetensi dan berbasis riset. Kurikulum berbasis kompetensi adalah kurikulum yang disusun berdasarkan elemen-elemen kompetensi yang dapat menghantarkan mahasiswa untuk mencapai kompetensi utama, pendukung, dan lainnya yang terkait. Kurikulum Berbasis Riset adalah kurikulum yang mendorong mahasiswa memecahkan masalah dengan cara penelitian/ilmiah (evidence based curriculum/problem solving).

\section{Proses Perubahan dan Penetapan Kurikulum}

Pada hakikatnya, kurikulum tidak cukup dipahami sebagai sebuah dokumen yang berharga dan dijadikan sebagai pedoman di dalam menyelenggarakan pendidikan di perguruan tinggi atau di sebuah jurusan atau program studinya.

Menurut S. Nasution (1980), keberhargaan dari dokumen kurikulum justru akan terletak pada nilainilai yang direalisasikan dari program-program pendidikan yang dilaksanakan.

Kurikulum sebelum dianggap selesai dan dapat digunakan dalam pendidikan tertentu biasanya dibicarakan melalui beberapa tahapan pembicaraan. Pada tahap awal, suatu kurikulum yang sedang berlaku dikritisi oleh para pakar atau praktisi seperti dosen jurusan Pendidikan Luar Biasa (PLB) atau juga oleh pengguna pendidikan yang dinilai atau dikritisi dari sisi kekurangan kurikulum dari segi implementasinya atau juga ada usulan-usulan dari stakeholder.

Kurikulum Jurusan PLB FIP UNJ baru saja di tahun 2010 ini disesuaikan dengan peraturan yang berlaku sehingga jumlah SKS secara keseluruhan tidak melebihi 144 SKS. Tetapi dengan dilaksanakannya studi banding dengan HNU khususnya program studi Special Educationnya, dan telah dilakukan juga MoU dengan HNU dan Fakultas Ilmu Pendidikannya, maka jurusan Pendidikan Luar Biasa Fakultas Ilmu Pendidikan UNJ harus berusaha membuat kurikulum yang disesuaikan dengan perkembangan science khusus di bidang special education.

\section{Konsep-konsep Kurikulum}

Kurikulum di perguruan tinggi nampaknya lebih banyak pada konsep akademik dan teknologi, kurikulum yang bertolak pada akademik memandang bahwa ilmu pengetahuan merupakan hal yang mendominasi dalam keseluruhan proses pendidikan. Kurikulum yang menganut konsep ini memiliki kecenderungan untuk mengembangkan daya intelektual dan penalaran mahasiswa untuk menguasai ilmu pengetahuan

Kurikulum di perguruan tinggi juga nampak nya menekankan pada media yang menentukan di dalam kegiatan pembelajaran. Kurikulum ini juga menyajikan teori dan prinsip-prinsip pengetahuan yang menjadi landasan terhadap aplikasinya di lapangan. Tetapi karena jurusan PLB yang mendidik calon-calon guru dan ahli di bidang pendidikan khusus maka di dalam kurikulumnya sudah pasti menganut konsep-konsep ilmu pendidikan, tanpa ilmu pendidikan nampaknya sulit untuk dapat membelajarkan siswa dengan baik, kurikulum ini sebenarnya tidak total menganut kedua konsep pertama dan kedua tetapi di dalam kurikulum jurusan PLB membagi mata kuliahnya menjadi lima bagian yaitu.

(1) Mata kuliah pengembangan kepribadian.

(2) Mata kuliah keilmuan dan keterampilan.

(3) Mata kuliah keahlian berkarya.

(4) Mata kuliah perilaku berkarya.

(5) Mata kuliah berkehidupan bermasyarakat.

Maka konsep-konsep kurikulum seperti kurikulum subjek akademi (perenialis dan esensial), proses pengembangan kognitif, rekonstruksi sosial, humanistik, dan kurikulum teknologi, kesemuanya sudah tercukupi.

\section{Kurikulum Berbasis Kompetensi (KBK)}

Kurikulum menjadi bagian yang terpenting dari keseluruhan proses pendidikan yang berlangsung di suatu lembaga pendidikan, kurikulum yang demikian adalah karena adanya perluasan makna kurikulum yang tidak lagi melihat kurikulum sebatas rencana 
pengajaran atau pembelajaran, tetapi sudah menjadi aktivitas pembelajaran untuk mencapai tujuan-tujuan pendidikan. Aktivitas pembelajaran adalah aktivitas belajar dari peserta didik yang difasilitasi oleh dosen dan manajemen institusi untuk mencapai tujuantujuan pendidikan (Hasibuan, 2010).

Menurut Koordinator Tim Kurikulum Berbasis Kompetensi Direktorat Jenderal Pendidikan Tinggi, Silvi Dewayani, kurikulum perguruan tinggi harus disusun berdasarkan kompetensi sehingga dapat meningkatkan kredibilitasnya di mata masyarakat. Untuk menciptakan perguruan tinggi yang memiliki kredibilitas tinggi harus dimulai dari penyusunan kurikulum yang membangun kompetensi para mahasiswanya (http://www.dikti.go.id/index.php?, 2010)

Pendidikan berbasis kompetensi menekankan pada kemampuan yang harus dimiliki oleh lulusan suatu jenjang pendidikan. Kompetensi yang sering disebut dengan standar kompetensi adalah kemampuan yang secara umum harus dikuasai lulusan. Kompetensi menurut Hall dan Jones (1976: 29) adalah "pernyataan yang menggambarkan penampilan suatu kemampuan tertentu secara bulat yang merupakan perpaduan antara pengetahuan dan kemampuan yang dapat diamati dan diukur" (http:/ / www.ditpertais.net/swara/warta17-03.asp)

Kompetensi (kemampuan) lulusan merupakan modal utama untuk bersaing di tingkat global, karena persaingan yang terjadi adalah pada kemampuan sumber daya manusia. Oleh karena. itu, penerapan pendidikan berbasis kompetensi diharapkan akan menghasilkan lulusan yang mampu berkompetisi di tingkat global. Implikasi pendidikan berbasis kompetensi adalah pengembangan silabus dan sistem penilaian berbasiskan kompetensi.

Surat Keputusan Mendiknas Nomor 045/U/ 2002. tentang Kurikulum Inti Perguruan Tinggi mengemukakan "Kompetensi adalah seperangkat tindakan cerdas, penuh tanggung jawab yang dimiliki seseorang sebagai syarat untuk dianggap mampu oleh masyarakat dalam melaksanakan tugas-tugas di bidang pekerjaan tertentu" (http://www.ditpertais.net/swara/warta17-03.asp)

Kurikulum berbasis kompetensi adalah kurikulum yang pada tahap perencanaan, terutama dalam tahap pengembangan ide akan dipengaruhi oleh kemungkinan-kemungkinan pendekatan, kompetensi dapat menjawab tantangan yang muncul. Artinya, pada waktu mengembangkan atau mengadopsi pemikiran kurikulum berbasis kompetensi maka pengembang kurikulum harus mengenal benar landasan filosofi, kekuatan, dan kelemahan pendekatan kompe- tensi dalam menjawab tantangan, serta jangkauan validitas pendekatan tersebut ke masa depan. Harus diingat bahwa kompetensi bersifat terus berkembang sesuai dengan tuntutan dunia kerja atau dunia profesi maupun dunia ilmu. Dengan demikian, kurikulum perguruan tinggi sudah tentu termasuk kurikulum jurusan Pendidikan Luar Biasa UNJ berpedoman pada SK Mendiknas no. 45/U/2002 di atas.

\section{Kurikulum S1 Jurusan PLB FIP UNJ}

Sebagai perbandingan dengan HNU, kurikulum S1 dirancang untuk menjadikan output guru PLB. Untuk mengantisipasi globalisasi yang telah masuk ke Indonesia, maka jurusan PLB FIP UNJ telah mengantisipasi dengan mengembangkan kurikulum internasional yaitu untuk jurusan PLB FIP UNJ program S1 sangat sulit dikembangkan double degree dengan S1 HNU, mengingat beberapa mata kuliah yang tidak dimungkinkan dipelajari oleh mahasiswa Indonesia seperti mata kuliah Marxism dan teori ideologi Mao Tse Dong. Hal ini karena Indonesia memiliki dasar negara yang berbeda dengan dasar negara Cina. Untuk mata kuliah yang bersifat demikian, ideologis sudah tentu harus menggunakan mata kuliah pendidikan pancasila, pendidikan kewarganegaraan, artinya kurikulum internasional jurusan PLB FIP UNJ disesuaikan dengan perkembangan ilmu pengetahuan khususnya special education dan special need.

\section{Kurikulum S2 Internasional Jurusan PLB FIP UNJ}

Kurikulum S2 yang direncanakan akan dilaksanakan pada tahun ajaran 2012 berisi dua alternatif yaitu master of education dan master of philosophy. Master of Education (M.Ed) menitikberatkan pada kuliah, praktikum, dan penelitian. Sedangkan pada Master of Philosophy (M.Phil) titik beratnya pada penelitian.

Master of Education disediakan untuk kepala sekolah, guru, dan berbagai praktisi dalam pendidikan. Sedangkan Master of Philosophy disediakan untuk kalangan dosen dan peneliti.

Dalam pelaksanaannya kelak kemungkinan adanya double degree program master of philosophy antara HNU dengan UNJ. Hal ini karena program S2 M.Phil titik beratnya pada penelitian. Sedangkan pada Master of Education di mana masih terdapat kuliah dan praktikum sehingga masih sulit dilaksanakan, karena perkuliahan harus mencakup ideologi dari suatu negara.

\section{METODOLOGI PENELITIAN}

\section{Tujuan Penelitian}

Tujuan penelitian ini adalah membandingkan 
kurikulum PLB FIP UNJ dengan kurikulum jurusan PLB HNU Cina, dan memperoleh kurikulum internasional jurusan PLB FIP UNJ

\section{Metode Penelitian}

Metode penelitian yang digunakan dalam penelitian ini adalah menggunakan metode deskriptif Sampel

Teknik pengambilan sampel yang digunakan adalah purposive maka yang digunakan dalam studi banding hanya Huazhong Normal University China dan Universitas Negeri Jakarta khususnya jurusan PLB FIP UNJ

\section{Tempat Penelitian}

Tempat penelitian terutama studi banding di Huazhong Normal University, Cina dan Universitas Negeri Jakarta, Indonesia, khususnya special education (pendidikan khusus) dan jurusan Pendidikan Luar Biasa (PLB) FIP UNJ.

\section{Waktu penelitian}

Penelitian dilakukan dari bulan April sampai dengan bulan Oktober 2010, dengan rincian (1) penyusunan proposal penelitian, (2) pengajuan proposal, (3) pelaksanaan studi banding, (4) penyusunan laporan penelitian, (5) seminar hasil penelitian, (6) memperbaiki laporan penelitian, dan (7) menyerahkan laporan hasil penelitian.

\section{Teknik Pengumpulan Data}

Data penelitian dikumpulkan melalui wawancara, perkuliahan, dan observasi, baik di HNU maupun di jurusan PLB FIP UNJ.

\section{Analisis Data}

Data yang sudah diperoleh baik melalui observasi, wawancara, maupun perkuliahan (seminar) dianalisis secara deskriptif kualitatif.

\section{HASIL DAN PEMBAHASAN}

\section{Umum Huazhong Normal University tentang; Gedung dan Fasilitas}

Huazhong Normal University (HNU) berdiri pada tahun 1903. Universitas ini berlokasi di kota Wuhan, provinsi Hubei, Cina. Berdiri di atas tanah seluas lebih dari 600.000 meter persegi. Fasilitas yang terdapat di HNU adalah perpustakaan terdiri dari 1.68 juta buku-buku tentang Cina, 200.000 buku tentang bahasa asing, 120.000 buku ancient (sejarah), serta 3000 audio dan video.

Selain perpustakaan, HNU juga menyediakan fasilitas olah raga yang salah satunya adalah gymnasium yang dapat menampung 3700 orang. Fasilitas olah raga terdiri dari indoor dan outdoor seperti kolam renang 50 meter, lapangan sepak bola dengan lintasan untuk atletik, fitness centre, dan lapangan bola basket. Mahasiswa juga diberikan fasilitas untuk memasuki klub-klub olah raga universitas.

Klinik universitas terdapat di dalam kampus. Klinik ini menyediakan pengobatan tradisional China, ruang operasi, klinik gigi, radiologi, dan fisioterapi. Selain itu, HNU menyediakan ruang makan (dinning hall) untuk mahasiswa dan dosen. Di kantin ini juga tersedia makanan muslim dan makanan China lainnya.

Fasilitas lain yang terdapat di HNU adalah asrama untuk mahasiswa baik lokal maupun international. Selain itu juga, terdapat akomodasi untuk staf pengajar dan administrasi yang berlokasi di dalam kampus.

\section{Program di HNU}

HNU terdiri dari 22 fakultas dinamakan dengan College yaitu College of Political Science and Law, College of Education, College of Psychology, College of Sociology, College of History and Cultural Studies, College of Economics, College of Life Science, College of Urban Planning and Enviromental Science, College of Information Engineering, College of Mathematics and Statistics, College of Physical Science and Technology, College of Chemistry, College of Management, College of Foreign Language, College of Music, College of Fine Arts, College of Physical Education, College of Literature, College of International Cultural Exchange, Department of Computer Science, Department of Information Management, and College of International Cultural Exchange.

HNU menawarkan program S1, S2, dan S3. Saat ini HNU menawarkan program doktor berjumlah 62 buah, program pascasarjana master sejumlah 106 buah, dan 52 buah program S1.

Program Sejarah, Bahasa dan literatur Cina, Pendidikan, Ilmu Politik, dan Physic adalah programprogram yang masuk dalam ranking terkemuka di Cina. Selain itu, HNU juga menawarkan program nondegree untuk program bahasa, program visiting scholars dalam berbagai spesialis yaitu general studies dimana belajarnya bersama-sama dengan mahasiswa S1, dan program untuk mahasiswa senior dimana ini adalah sama tingkatannya dengan pascasarjana atau mahasiswa tingkat Ph.D.

Untuk saat ini, mahasiswa yang terdapat di HNU berjumlah lebih dari 20.000 orang dengan 5.400 mahasiswa pascasarjana dan terdiri dari mahasiswa asing dan lokal. Mahasiswa asing tersebut berasal dari 37 negara termasuk berasal dari Indonesia.

\section{Perkembangan Kurikulum di Cina}

Kurikulum di Cina mengalami reformasi 8 kali. 
Reformasi I pada tahun 1949-1952. Pada saat ini, hubungan Cina dengan Rusia sangat erat sekali, sehingga dampaknya adalah seluruh mata pelajaran di Cina adalah sama dengan yang ada Rusia. Akibatnya keunikan dari Cina hampir terlupakan.

Reformasi ke II di Cina diadakan pada tahun 1953 - 1957. Di sini terlihat kendala yaitu kurikulum berubah terlalu cepat sehingga sekolah-sekolah tidak dapat mengikuti perubahan tersebut.

Reformasi ke III pada tahun 1957 - 1963. Pada bulan Februari 1957, Mao Tse Dong seorang tokoh Cina Baru menyatakan bahwa tujuan dari pendidikan di Cina adalah harus mendidik anak-anak dalam moral, pengetahuan, dan olah raga berdasarkan ideologi sosialis. Stuktur yang pertama adalah moral kemudian pengetahuan lalu olah raga.

Reformasi ke IV pada tahun 1964 - 1976 menghasilkan bahwa semua kurikulum dan mata pelajaran harus diubah semua secara total. Ini adalah permintaan dari tokoh Cina yaitu Mao Tse Dong. Pada tahun ini, Mao berpendapat bahwa karena banyaknya penduduk di Cina sedangkan sekolah terbatas maka untuk masuk sekolah harus diadakan tes.

Reformasi ke V di Cina adalah pada tahun 19771980. Pada tahun 1976, Deng Xiao Ping menyatakan Cina terbuka untuk dunia. Deng sadar bahwa ternyata teknologi Cina jauh tertinggal dengan dunia barat. Pada masa ini, pemerintah mengubah sistem pendidikan yaitu (1) tingkatan sekolah dasar adalah 5 tahun dan sekolah menengah adalah 5 tahun (terdiri dari SMP dan SMA), (2) Departemen Pendidikan mengembangkan sistem pendidikan sentralisasi, dan (3) pemerintah membuat buku-buku materi ajar.

Reformasi ke VI adalah tahun 1981-1984. Pada masa ini, Deng menyatakan bahwa Cina harus mengembangkan sekolah-sekolah terbaik untuk tingkatan sekolah dasar dan menengah. Namun, masyarakat harus membayar lebih apabila memasukkan anak-anak mereka ke sekolah-sekolah ini.

Reformasi ke VII pada tahun 1985-1998, menghasilkan kompulsori pendidikan 9 tahun. Di sini pendidikan tidak dapat dipengaruhi lagi oleh politik. Nampak disini Cina telah mendapat pengaruh dari Amerika ketimbang dari Rusia.

Reformasi ke VIII adalah tahun 1999 - sampai sekarang. Pada masa ini fokus kurikulum adalah inovasi dan implementasi dari kemampuan siswa. Dasar dari teori reformasi ini adalah konstruktivisme, intelegensi jamak, humanis, dan filosofis postmodern.

Istilah kurikulum di Cina sudah ada sejak zaman Dinasti Tang yaitu Ke Ceng. Ke artinya satu mata pelajaran. Ceng artinya jalan atau cara. Ke Ceng artinya kurikulum. Kong Fu Tse, seorang tokoh di Cina menuliskan tentang enam seni sebagai hal-hal yang harus dipelajari yaitu ritual, musik, berburu (archery carriage: driving, or horse riding), kaligrafi, dan matematika.

Di masa lalu, kurikulum di Cina terdiri dari 4 buku dan 5 kitab yang harus dihafal oleh setiap orang. Empat buku tersebut dibagi menjadi beberapa topik yaitu belajar tinggi (the great learning), analitik dari Confusius, pekerjaan dari Mencius (murid dari Kong $\mathrm{Fu}$ Tse), dan doktrin tentang pengertian. Lima kitab terbagi atas topik-topik: buku tentang lagu; buku tentang pekerjaan; buku tentang perubahan; serta buku tentang tahunan ritual, musim semi, dan musim gugur. Empat buku ini berdasarkan masa Dinasti Song dan lima kitab berdasarkan Dinasti Han.

\section{Kurikulum Huazhong Normal University}

Struktur kurikulum yang wajib diambil oleh semua mahasiswa adalah terdiri dari kurikulum pendidikan umum, kurikulum dasar khusus, serta kurikulum khusus dan praktis.

Pada kurikulum pendidikan umum semua mahasiswa harus mengambil mata kuliah.

(1) Ideologi dan perencanaan moral.

(2) Pengantar idealis Mao Tse Dong.

(3) Bahasa asing (membaca dan menulis) 1 sampai dengan 3.

(4) Bahasa asing (berbicara dan mendengar) 1 sampai dengan 3.

(5) Komputer dasar.

(6) Matematika lanjutan.

(7) Olah raga I (fokus pada menyelematkan negara), olah raga II, dan olah raga III.

(8) Teori militer.

(9) Teknologi aplikasi data base.

(10) Multimedia dan aplikasi.

(11) Marxims (hubungan dengan ekonomi dan politik).

(12) Dasar-dasar hukum (bagaimana menjadi masyarakat sipil yang baik).

(13) Teori dari Deng Xiao Ping dan Tiga Representatif (hubungan dengan pengantar idealisme Mao Tse Dong).

(14) Marxims (filosofis).

(15) Studi kontemporer tentang ekonomi dan berbagai politik.

Setiap mahasiswa harus memiliki satu kemampuan khusus dalam olah raga atau seni, dan ini bernilai 3 kredit poin.

Kurikulum dasar khusus terdiri dari materi kuliah yang ada di fakultas seperti modern chinese 1 dan 2. Sebagai guru di China, mahasiswa harus menguasai dialek standar yaitu dialek dari daerah utara. 
Pada waktu sertifikasi guru ada ujian praktik Pu Dong Hua (mandarin standar).

Kurikulum khusus adalah mata kuliah yang ada di jurusan terdiri dari: (1) latihan militeri selama 3 minggu (fokusnya pada membangun sosialisasi di antara sesama mahasiswa), (2) latihan mengajar selama 6 minggu pada semester ke 7, (3) internship selam 6-8 minggu. Biasanya dilakukan pada libur musim dingin dan diatur oleh pihak universitas, (4) desain penelitian, (5) piket (misalnya membersihkan universitas), dan (6) layanan kepada masyarakat (menjadi pekerja sosial di Sekolah Luar Biasa, pantipanti, di jalanan dan sebagainya). Ini dilakukan pada libur-libur musim panas dan musim dingin.

Bagi mahasiswa lulusan dari universitas murni dan ingin menjadi guru harus mengambil degree ke dua. Total kredit poin adalah 65. HNU tidak ada spesifik untuk menjadi guru seperti di Universitas Negeri Jakarta (UNJ), semua disediakan untuk guru umum.

Kredit poin maksimum adalah 168. Di bawah ini contoh dari kredit poin:

Tabel 1. Contoh Kredit Poin Maksimum S1 HNU

\begin{tabular}{|c|l|l|l|l|l|l|l|l||}
\hline \multicolumn{2}{|c|}{} & \multicolumn{2}{|c|}{$\begin{array}{c}\text { Kurikulum } \\
\text { Pendidikan } \\
\text { Umum }\end{array}$} & $\begin{array}{c}\text { Area } \\
\text { Kurikulum } \\
\text { Dasar }\end{array}$ & \multicolumn{2}{c|}{$\begin{array}{c}\text { Kurikulum } \\
\text { Khusus }\end{array}$} & $\begin{array}{c}\text { Kurikulum } \\
\text { Praktik }\end{array}$ \\
\hline \multirow{3}{*}{$\begin{array}{c}\text { Kre } \\
\text { dit }\end{array}$} & & RC & SC & RC & SC & RC & SC & RC \\
\cline { 2 - 9 } & Seni & 52 & 24 & A1 & A2 & A3 & A4 & $23-27$ \\
\cline { 2 - 10 } & Sain & 49 & 24 & S1 & S2 & S3 & S4 & $23-27$ \\
\hline \hline
\end{tabular}

Catatan: RC: Required Course, SC: Selective Course

\section{Kurikulum S1 Jurusan Pendidikan Luar Biasa (PLB) di HNU}

Bagi mahasiswa yang ingin menjadi guru PLB harus mengambil materi kuliah dari kurikulum PLB yaitu.

Tabel 2. Kurikulum S1 Jurusan PLB HNU

\begin{tabular}{|l|l|l|c|}
\hline \hline Aspek & Tipe & Nama mata kuliah & Kredit \\
\hline $\begin{array}{l}\text { Pendidikan } \\
\text { Umum }\end{array}$ & Wajib & Sama seperti yang lain & \\
\hline $\begin{array}{l}\text { Area } \\
\text { Kurikulum } \\
\text { Dasar }\end{array}$ & \multirow{2}{*}{ Wajib } & Psikologi Umum I & 3 \\
\cline { 3 - 4 } & & $\begin{array}{l}\text { Anatomi manusia dan } \\
\text { fisiologi }\end{array}$ & 3 \\
\cline { 3 - 4 } & Pengantar Pendidikan & 4 \\
\cline { 3 - 4 } & Psikologi Umum 2 & 2 \\
\cline { 3 - 4 } & Psikologi Perkembangan & 3 \\
\cline { 3 - 4 } & $\begin{array}{l}\text { Kurikulum dan } \\
\text { Pedagogik }\end{array}$ & 4 \\
\cline { 3 - 4 } & $\begin{array}{l}\text { Metode Penelitian } \\
\text { Pendidikan }\end{array}$ & 3 \\
\hline
\end{tabular}

\begin{tabular}{|c|c|c|c|}
\hline Aspek & Tipe & Nama mata kuliah & Kredit \\
\hline \multirow{16}{*}{$\begin{array}{l}\text { Area Khusus } \\
\text { Kurikulum }\end{array}$} & \multirow[t]{16}{*}{ Waijb } & TeknologiPendidikan & 2 \\
\hline & & Pengantar Pendidikan Khusus & 3 \\
\hline & & Psychometrik & 4 \\
\hline & & $\begin{array}{l}\text { Psikologi dan pendidikan bagi anak } \\
\text { dengan gangoguan penglihatan }\end{array}$ & 3 \\
\hline & & Perbandingan Pendidikan Khusus & 2 \\
\hline & & $\begin{array}{l}\text { Pathologi anak dengan kebutuhan } \\
\text { khusus }\end{array}$ & 2 \\
\hline & & English untuk Pendidikan Khusus & 2 \\
\hline & & $\begin{array}{l}\text { Diagnosis anak dengan kebutuhan } \\
\text { khusus }\end{array}$ & 3 \\
\hline & & $\begin{array}{l}\text { Psikhologi dan pendidikan untuk } \\
\text { tunagrahita }\end{array}$ & 3 \\
\hline & & $\begin{array}{l}\text { Teori Rehabilitasi untuk anak cacat } \\
\text { (Disabled Children) }\end{array}$ & 2 \\
\hline & & $\begin{array}{l}\text { Psikhologi dan pendidikan untuk } \\
\text { anak dengan gangguan } \\
\text { pendengaran }\end{array}$ & 3 \\
\hline & & $\begin{array}{l}\text { Theori dan praktis dalam } \\
\text { pendidikan inklusif }\end{array}$ & 2 \\
\hline & & $\begin{array}{l}\text { Sejarah Pendidikan Khusus (China } \\
\text { dan Negara-negara lain) } \\
\end{array}$ & 2 \\
\hline & & $\begin{array}{l}\text { Studi tentang bahasa bicara dan } \\
\text { pendengaran (Speech Language } \\
\text { and Hearing Study) }\end{array}$ & 2 \\
\hline & & Braille dan Bahasa Isyarat & 3 \\
\hline & & $\begin{array}{l}\text { Latihan Ketrampilan guru (Teacher } \\
\text { Skill Training) }\end{array}$ & 1 \\
\hline \multirow[t]{13}{*}{ Pilihan } & & $\begin{array}{l}\text { Psikologi dan pendidikan untuk } \\
\text { anak-anak abnormal [Psychology } \\
\text { and Education for Abnormal } \\
\text { Children (stress on gifted and } \\
\text { talented)] }\end{array}$ & 3 \\
\hline & & Sejarah pendidikan di China & 4 \\
\hline & & $\begin{array}{l}\text { Sejarah pendidian di Negara-negara } \\
\text { lain }\end{array}$ & 4 \\
\hline & & SPSS (Basic and Application) & 2 \\
\hline & & $\begin{array}{l}\text { Psikologi cognitive untuk anak- } \\
\text { anak dengan kebutuhan khusus }\end{array}$ & 2 \\
\hline & & $\begin{array}{l}\text { Intervensi dini untuk anak-anak } \\
\text { dengan kebutuhan khusus }\end{array}$ & 2 \\
\hline & & $\begin{array}{l}\text { Kebijakan dan legislasi Pendidikan } \\
\text { Khusus (Special Education Policy } \\
\text { and Legislation) }\end{array}$ & 2 \\
\hline & & Genetic dan Eugenic & 2 \\
\hline & & Psikologi pendidikan & 4 \\
\hline & & Psikologi social & 2 \\
\hline & & Learning Disabilities dan Autism & 2 \\
\hline & & Filsafat dalam pendidikan & 3 \\
\hline & & $\begin{array}{l}\text { Gangouan tingkah laku dan koreksi } \\
\text { (Behavior Disorders and } \\
\text { Correction) }\end{array}$ & 2 \\
\hline
\end{tabular}

Perspektif Ilmu Pendidikan - Vol.23 Th. XIV April 2011 


\begin{tabular}{|l|l|l|l|}
\hline \hline Aspek & Tipe & Nama mata kuliah & Kredit \\
\hline Pilihan & Studi dalam evaluasi pendidikan & 2 \\
\hline & & Teori Bermain dan Bimbingan & 2 \\
\hline & Orientasi and Mobilitas & 2 \\
\hline & Psikologi Konseling & 3 \\
\hline & $\begin{array}{l}\text { Pendidikan pengasuhan (Parenting } \\
\text { Education) }\end{array}$ & 2 \\
\hline & $\begin{array}{l}\text { Reformasi Pendidikan Saat in di } \\
\text { China (seminar dalam topic } \\
\text { pendidikan khusus) }\end{array}$ \\
\hline & Pratik dalam Pendidikan Khusus & 2 \\
\hline
\end{tabular}

Rancangan kurikulum ditentukan oleh Perguruan Tinggi masing-masing atau tidak ada standarisasi.

Standar kurikulum ditentukan oleh masingmasing dosen dan universitas. Nama mata kuliah ditentukan oleh universitas sedangkan isi mata kuliah oleh dosen yang bersangkutan.

\section{Gambaran Umum Universitas Negeri Jakarta (UNJ) Gedung dan Fasilitas}

UNJ dahulu bernama IKIP (Institut Keguruan dan Ilmu Pendidikan). Melalui Keputusan Presiden RI No. 1 tahun 1963 tanggal 3 Januari 1963, ditetapkan integrasi sistem kelembagaan pendidikan guru salah satu butir pernyataan Kepres tersebut adalah bahwa surat keputusan ini berlaku sejak 16 Mei 1964, yang kemudian dinyatakan sebagai hari lahirnya IKIP Jakarta. FKIP dan IPG diubah menjadi IKIP (Institut Keguruan dan Ilmu Pendidikan).

Proses pengintegrasian FKIP-Universitas Indonesia dan IPG Jakarta, melahirkan IKIP Jakarta. Dalam perkembangan selanjutnya, IKIP Jakarta setelah berusia lebih kurang 36 tahun, sejak tanggal 4 Agustus 1999 berubah menjadi Universitas Negeri Jakarta (UNJ) berdasarkan Keppres 093/1999 tanggal 4 Agustus 1999, dan peresmiannya dilaksanakan oleh Presiden Republik Indonesia pada tanggal 31 Agustus 1999 di pendidikan yaitu "... membentuk manusia Pancasila dan Manipol/Usdek yang bertanggung jawab antara lain terselenggaranya masyarakat adil dan makmur, materiil dan spiritual". Selanjutnya menurut Hernawan, dkk (2006); sistem rencana pendidikan sekolah dasar pada saat itu dikenal dengan Sistem Pancawardana atau lima aspek perkembangan yaitu perkembangan moral, perkembangan intelegensi, perkembangan emosional artistik, perkembangan keprigelan, dan perkembangan jasmaniah.

Pada tahun 1968 terjadi lagi perubahan kurikulum, dan hal ini terjadi lagi pada tahun 1975. Pada tahun 1983 dengan Surat Keputusan Menteri Pendidikan dan Kebudayaan Nomor 0461/U/1983 tentang perbaikan kurikulum diberlakukan kurikulum baru yaitu kurikulum 1984. Terjadi lagi perubahan kurikulum yaitu tahun 1994, 2004, dan sekarang kurikulum tingkat satuan pendidikan atau KTSP.

Untuk pendidikan tinggi, pemerintah melakukan otonomi pada tiap perguruan tinggi untuk mengatur kurikulum. Terlebih dengan adanya pendidikan profesi guru, dimana setiap lulusan perguruan tinggi yang menyelenggarakan program keguruan, maka lulusannya belum menjadi guru sebelum lulus pendidikan profesi.

\section{Kurikulum Jurusan PLB FIP UNJ}

Tabel 3. Kurikulum Jurusan PLB FIP UNJ

\begin{tabular}{|c|c|c|c|}
\hline $\begin{array}{c}\text { Kode } \\
\text { MK }\end{array}$ & Nama Mata Kuliah & SKS & Prasyarat \\
\hline & Pendidikan Agama & 3 & \\
\hline & Pendidikan Kewarganegaraan & 3 & \\
\hline & Bahasa Indonesia & 2 & \\
\hline & Bahasa Inggris & 2 & \\
\hline & Statistika & 2 & \\
\hline & ISBD/IAD & 3 & \\
\hline Jumlah & & 13 & \\
\hline Kode MK & Nama Mata Kuliah & SKS & Prasyarat \\
\hline $005-213-4$ & Pengantar Ilmu Pendidikan & 4 & \\
\hline 005-215-2 & Psikologi Perkembangan & 2 & \\
\hline $005-214-4$ & $\begin{array}{l}\text { Teori Belajar dan } \\
\text { Pembelajaran }\end{array}$ & 4 & \\
\hline $005-212-2$ & Profesi Kependidikan & 2 & \\
\hline $1335-001-2$ & $\begin{array}{l}\text { Pengantar Pendidikan } \\
\text { Khusus }\end{array}$ & 2 & \\
\hline $1335-005-2$ & $\begin{array}{l}\text { Pembelajaran Bahasa untuk } \\
\text { Anak dengan Kebutuhan } \\
\text { khusus }\end{array}$ & 2 & $1335-001-2$ \\
\hline 1335-006-2 & $\begin{array}{l}\text { Pembelajaran Matematika } \\
\text { untuk Anak dengan } \\
\text { Kebutuhan khusus }\end{array}$ & 2 & $1335-001-2$ \\
\hline $1335-007-2$ & $\begin{array}{l}\text { Pembelajaran Sains (IPA) } \\
\text { untuk Anak dengan } \\
\text { Kebutuhan khusus }\end{array}$ & 2 & $1335-001-2$ \\
\hline $1335-008-2$ & $\begin{array}{l}\text { Pembelajaran Ilmu Sosial } \\
\text { untuk Anak dengan } \\
\text { Kebutuhan khusus }\end{array}$ & 2 & $1335-001-2$ \\
\hline $1335-009-2$ & $\begin{array}{l}\text { Pembelajaran Seni Musik } \\
\text { untuk Anak dengan } \\
\text { Kebutuhan khusus }\end{array}$ & 2 & $1335-001-2$ \\
\hline $1335-064-2$ & $\begin{array}{l}\text { Pembelajaran Seni Tari untuk } \\
\text { Anak dengan Kebutuhan } \\
\text { khusus }\end{array}$ & 2 & $1335-001-2$ \\
\hline $1335-010-2$ & $\begin{array}{l}\text { Pembelajaran Seni Rupa dan } \\
\text { Kerajinan untuk Anak } \\
\text { dengan Kebutuhan khusus }\end{array}$ & 2 & $1335-001-2$ \\
\hline 1335-011-2 & Pendidikan Jasmani Adaptif & 2 & $1335-001-2$ \\
\hline $1335-013-2$ & $\begin{array}{l}\text { Bimbingan \& Konseling } \\
\text { Anak dengan Kebutuhan } \\
\text { khusus }\end{array}$ & 2 & $1335-001-2$ \\
\hline $1335-107-2$ & $\begin{array}{l}\text { Perspektif Pendidikan Anak } \\
\text { Tunanetra }\end{array}$ & 2 & $1335-001-2$ \\
\hline $1335-108-2$ & Pembelajaran Tunanetra & 2 & $1335-107-2$ \\
\hline $1335-018-2$ & Orientasi dan Mobilitas & 2 & $1335-107-2$ \\
\hline $1335-019-2$ & Braille & 2 & $1335-107-2$ \\
\hline 1335-099-2 & $\begin{array}{l}\text { Pendalaman Pendidikan } \\
\text { Anak Tunanetra *) }\end{array}$ & 2 & $1335-019-2$ \\
\hline $1335-109-2$ & $\begin{array}{l}\text { Perspektif Pendidikan } \\
\text { Tunarungu }\end{array}$ & 2 & $1335-001-2$ \\
\hline $1335-110-2$ & Pembelajaran Tunarungu & 2 & $1335-109-2$ \\
\hline $1335-023-2$ & $\begin{array}{l}\text { Bina Persepsi Bunyi dan } \\
\text { Irama }\end{array}$ & 2 & $1335-109-2$ \\
\hline
\end{tabular}




\begin{tabular}{|c|c|c|c|}
\hline Kode MK & Nama Mata Kuliah & SKS & Prasyarat \\
\hline $1335-102-2$ & $\begin{array}{l}\text { Pendalaman Pendidikan } \\
\text { Anak Tunadaksa *) }\end{array}$ & 2 & $1335-113-2$ \\
\hline $1335-116-2$ & $\begin{array}{l}\text { Perspektif Pendidikan } \\
\text { Anak dengan Gangguan } \\
\text { Emosi dan Tingkah } \\
\text { Laku (GETL) }\end{array}$ & 2 & $1335-001-2$ \\
\hline $1335-117-3$ & $\begin{array}{l}\text { Pembelajaran Anak } \\
\text { dengan GETL }\end{array}$ & 3 & $1335-116-2$ \\
\hline $1335-103-2$ & $\begin{array}{l}\text { Pendalaman Pendidikan } \\
\text { Anak GETL *) }\end{array}$ & 2 & $1335-116-2$ \\
\hline $1335-118-2$ & $\begin{array}{l}\text { Perspektif Pend. Anak } \\
\text { Kesulitan Belajar }\end{array}$ & 2 & $1335-001-2$ \\
\hline $1335-043-2$ & $\begin{array}{l}\text { Pembelajaran Anak } \\
\text { Kesulitan Belajar Pra } \\
\text { Akademik }\end{array}$ & 2 & $1335-118-2$ \\
\hline 1335-044-2 & $\begin{array}{l}\text { Pembelajaran Anak } \\
\text { Kesulitan Belajar } \\
\text { Akademik }\end{array}$ & 2 & $1335-118-2$ \\
\hline 1335-104-2 & $\begin{array}{l}\text { Pendalaman Pend. Anak } \\
\text { Kesulitan Belajar *) }\end{array}$ & 2 & $1335-118-2$ \\
\hline $1335-119-2$ & $\begin{array}{l}\text { Perspektif Anak Autis } \\
\text { dan Gangguan } \\
\text { Pemusatan Perhatian } \\
\text { dan Hiperaktif (GPPH) }\end{array}$ & 2 & $1335-001-2$ \\
\hline $1335-047-2$ & $\begin{array}{l}\text { Pembelajaran Anak } \\
\text { Autis dan Pembelajaran } \\
\text { Anak dengan GPPH }\end{array}$ & 2 & $1335-119-2$ \\
\hline $1335-106-2$ & $\begin{array}{l}\text { Pendalaman Pend. Anak } \\
\text { Autis dan GPPH *) }\end{array}$ & 2 & $1335-119-2$ \\
\hline \multirow[t]{2}{*}{$1335-073-2$} & $\begin{array}{l}\text { Perspektif Pendidikan } \\
\text { Anak Berbakat }\end{array}$ & 2 & $1335-001-2$ \\
\hline & $\begin{array}{l}\text { Pembelajaran Anak } \\
\text { Berbakat }\end{array}$ & 4 & $1335-073-2$ \\
\hline $1335-105-2$ & $\begin{array}{l}\text { Pendalaman Pendidikan } \\
\text { Anak Berbakat*) }\end{array}$ & 2 & $1335-073-2$ \\
\hline $1335-120-4$ & $\begin{array}{l}\text { Pendidikan anak } \\
\text { tunaganda }\end{array}$ & 4 & $1335-001-2$ \\
\hline $1335-057-2$ & Neuroanatomi & 2 & $1335-001-2$ \\
\hline 1335-059-2 & Psikiatri & 2 & $1335-001-2$ \\
\hline 1335-121-2 & $\begin{array}{l}\text { Kecenderungan Baru } \\
\text { dalam PLB }\end{array}$ & 2 & $1335-001-2$ \\
\hline \multicolumn{2}{|r|}{ Jumlah } & 91 & \\
\hline Kode MK & Nama Mata Kuliah & SKS & Prasyarat \\
\hline $1335-014-2$ & $\begin{array}{l}\text { Bina Wicara bagi Anak } \\
\text { Gangguan Komunikasi }\end{array}$ & 2 & \\
\hline $1335-014-4$ & $\begin{array}{l}\text { Asesmen Anak } \\
\text { Berkebutuhan Khusus }\end{array}$ & 4 & $1005-105-2$ \\
\hline $1335-078-2$ & $\begin{array}{l}\text { Media dan Teknologi } \\
\text { Adaptif }\end{array}$ & 2 & $1005-105-2$ \\
\hline $1335-004-2$ & Evaluasi Pembelajaran & 2 & $1005-105-2$ \\
\hline 1335-015-4 & $\begin{array}{l}\text { Metodologi Penelitian } \\
\text { Lanjutan }\end{array}$ & 4 & $1005-105-2$ \\
\hline $1005-105-2$ & $\begin{array}{l}\text { Pengantar Metodologi } \\
\text { Penelitian }\end{array}$ & 2 & \\
\hline \multicolumn{2}{|r|}{ Jumlah } & 16 & \\
\hline Kode MK & Nama Mata Kuliah & SKS & Prasyarat \\
\hline $1335-012-2$ & $\begin{array}{l}\text { Pembinaan Kompetensi } \\
\text { Mengajar (PKM) }\end{array}$ & 2 & $1005-105-2$ \\
\hline 1335-016-1 & Seminar Usulan Penelitian & 1 & \\
\hline $1335-017-1$ & Seminar Hasil Penelitian & 1 & $1335-016-1$ \\
\hline $1005-402-4$ & Skripsi & 4 & $1335-017-1$ \\
\hline \multicolumn{2}{|r|}{ Jumlah } & 8 & \\
\hline Kode MK & Nama Mata Kuliah & SKS & Prasyarat \\
\hline $1005-207-2$ & $\begin{array}{l}\text { Manajemen dan Advokasi } \\
\text { dalam Pendidikan Khusus }\end{array}$ & 2 & $1005-105-2$ \\
\hline 13250014 & Intership & 4 & $1005-105-2$ \\
\hline $1005-209-4$ & $\begin{array}{l}\text { Kuliah Kerja Nyata (KKN) } \\
\left.{ }^{*}\right)\end{array}$ & 4 & \\
\hline \multicolumn{2}{|r|}{ Jumlah } & $6-10$ & \\
\hline
\end{tabular}

\section{Analisis Data}

\section{Gambaran Umum}

Huazhong Normal University (HNU) merupakan universitas yang bergerak di bidang pendidikan, dilihat dari kata "Normal" yang berarti pendidikan, sedangkan Universitas Negeri Jakarta (UNJ) terdiri dari bidang pendidikan dan nonkependidikan. Ini berarti keluaran UNJ tidak hanya menjadi guru tetapi menjadi nonguru.

Fasilitas yang terdapat di HNU jauh lebih baik daripada UNJ. HNU dilengkapi dengan fasilitas asrama untuk mahasiswa lokal dan internasional yang dilengkapi dengan dapur dan ruang cuci, akomodasi untuk pengajar dan staf lainnya, sedangkan asrama mahasiswa di UNJ, baru untuk mahasiswa jurusan PGSD dengan program PGSD berasrama. Sedangkan untuk dosen dan staf lainnya, UNJ belum optimal dalam penyediaan akomodasi.

Untuk fasilitas mahasiswa seperti sarana olah raga, klinik, kesenian dan perpustakaan, HNU lebih baik karena dengan luas lebih dari 600.000 meter persegi HNU dapat menyediakan sarana yang berstandar internasional. Dalam kampus HNU juga dilengkapi dengan kantin untuk mahasiswa muslim. Berdasarkan observasi berdekatan dengan kampus HNU terdapat beberapa supermarket, toko-toko dan pasar tradisional serta berbagai restoran termasuk restoran muslim yang dapat memenuhi kebutuhan mahasiswa dan anggota universitas. Sementara UNJ belum optimal dalam menyediakan berbagai fasilitas tersebut.

Namun terdapat kelebihan dari UNJ yaitu penyediaan free wifi internet, sementara di HNU mahasiswa dan dosen dapat berinternet gratis di dalam kamar asrama dan di ruang dosen. Namun di kelas-kelas HNU, dosen dapat mengakses internet dengan mudah melalui sarana internet yang ada di meja dosen.

Untuk multimedia, HNU telah melengkapi di setiap kelas, namun untuk UNJ, dosen masih harus membawa laptop masing-masing.

\section{Program}

Program di HNU lebih banyak daripada yang ada di UNJ. HNU memiliki program PLB untuk jenjang S1 sampai dengan S3, sementara UNJ tidak memiliki program tersebut. Namun UNJ telah memiliki program S1 sampai dengan S3 untuk PG PAUD, sedangkan HNU hanya untuk S1 dan S2.

\section{Perkembangan Kurikulum}

Cina telah mengembangkan kurikulum sejak zaman Dinasti Tang. Sejak saat itu, kurikulum di Cina telah melalui berbagai perubahan termasuk dalam 
bahan ajar. Di Indonesia tercatat sejak zaman penjajahan, kemungkinan penjajah menghapus seluruh data yang berkaitan dengan kurikulum dan pendidikan sejak zaman kerajaan-kerajaan besar.

\section{Kurikulum PLB}

Jurusan PLB FIP UNJ memiliki mata kuliah yang lebih lengkap daripada jurusan PLB HNU. Dilihat dari jumlah mata kuliah dan jenis kebutuhan khusus yang disediakan, UNJ ternyata lebih detail. Jenis kebutuhan khusus yang disediakan oleh jurusan PLB UNJ yaitu mulai dari gangguan visual, auditori, dan bahasa serta komunikasi, intelektual, fisik dan kesehatan, emosi dan perilaku, anak berbakat, anak dengan kesulitan belajar, anak dengan autisme, dan anak dengan ADHD (Atention Deficit Hyperactive Disorder).

HNU hanya memiliki beberapa mata kuliah kekhususan dan apabila diamati kebanyakan mata kuliah di HNU berhubungan dengan psikologi. Sedangkan di UNJ penekanan mata kuliah pada pendidikan, asesmen, dan pembelajaran.

\section{PENUTUP}

\section{Kesimpulan}

Berdasarkan hasil studi banding dengan HNU secara umum dan secara khusus kurikulum jurusan special education HNU dan pengkajian kurikulum jurusan PLB FIP UNJ khusus untuk tahun 2010 maka kurikulum PLB FIP UNJ lebih komprehensif dan kompetensi yang harus dicapai mahasiswa terdiri dari lima bidang yaitu pengembangan kepribadian, keilmuan dan keterampilan, keahlian berkarya, perilaku berkarya, dan berkehidupan bermasyarakat

Berarti kurikulum internasional jurusan Pendidikan Luar Biasa (PLB) FIP Universitas Negeri Jakarta (UNJ) sudah dapat digunakan bila ada mahasiswa dari luar negeri termasuk di Cina khususnya HNU yang berminat kuliah di special education FIP UNJ.

Fasilitas yang belum siap adalah perpustakaan yang lengkap, internet (lab internet) yang memadai, ruang kelas yang ber $\mathrm{AC}$, dan sudah siap media pembelajarannya seperti LCD, laptop, dan tempat belajar lain di lingkungan UNJ, dan tempat bermalam seperti di HNU kebetulan UNJ belum memilikinya, termasuk kantin yang lebih memadai.

\section{Saran-Saran}

Seharusnya fakultas-fakultas dan UNJ bila banyaknya mahasiswa dari luar negeri yang belajar atau menempuh pendidikan sebagai ukuran salah satu jenis keunggulannya maka perlu disiapkan antara lain, perpustakaan yang menyediakan buku-buku baru secara komprehensif termasuk juga di setiap fakultas, disediakan tempat bermalam (wisma) yang sangat memadai dan tersedia TV, dan internet di setiap kamar tetapi dengan sewa yang terjangkau oleh mahasiswa luar negeri, ruang kelas bagus, dan ber AC (sejuk), minimal sudah tersedia LCD, dan whiteboard yang bagus, disediakan restoran yang menyediakan bermacam-macam menu, kalau perlu ada juga CFC, dan disediakan juga tempat belajar selain di dalam kelas yaitu seperti di lobi tetapi yang sejuk (AC).

\section{DAFTAR PUSTAKA}

Dikti. (2010). Kurikulum perguruan tinggi harus berdasar kompetensi. Diakses pada tanggal 13 Juni 2010 dari http:/ / www.dikti.go.id/index.-php?option=com_content\&view=article\&id=1139:kurikulumperguruan-tinggi-harus-berdasar-kompetensi\&catid=69:berita-terkait\&Itemid=196.

Hasan, S.H. (2006). Perkembangan kurikulum: Perkembangan ideologis dan teoretik pedagogis (1950-2005). Diakses pada tanggal 13 Juni 2010 darihttp:/ / www.geocities.ws/konferensinasionalsejarah/s_hamid_hasan.pdf.

Hasibuan, L. (2010). Kurikulum dan pemikiran pendidikan. Jakarta: Gaung Persada.

Hernawan, A., dkk. (2004). Hakikat kurikulum, pengembangan kurikulum dan pembelajaran. Jakarta: Universitas Terbuka.

HNU. (2010). Kurikulum HNU jurusan special education. Cina: Wuhan.

Infed. (2000). Curriculum and practice. Diakses pada tanggal 13 Juni 2010 dari http://www.infed.org/biblio/b-curric.htm.

Labschool UNJ. Kurikulum. Diakses pada tanggal 13 Juni 2010 dari http://www.labschoolunj.sch.id/doc/PG-TK/kurikulum.pdf.

Nasution, S. (1980). Azas-azas kurikulum. Bandung: Jenmars.

PLB. (2010). Kurikulum jurusan PLB FIP UNJ tahun 2010. Jakarta: PLB FIP UNJ.

Sudrajat, A. (2009). Kurikulum berdasarkan filsafatbehaviourisme. Diakses pada tanggal 13 Juni 2010 dari http:/ / akhmadsudrajat.word-press.com/ 2009/05/12.

Surat Keputusan Mendiknas nomor 045/U/2002 tentang Kurikulum inti perguruan tinggi.

Swara Ditpertais. (2004). Kurikulum berbasis kompetensi. Swara Ditpertais No. 17 Th. II, 18 Oktober 2004. Diakses pada tanggal 13 Juni 2010 dari http:/ / www.ditper-tais.net/swara/warta17-03.asp. 


\section{KETERANGAN PENULIS}

Nirsantono Hasnul, saat ini bertugas sebagai dosen tetap di jurusan Pendidikan Luar Biasa Fakultas Ilmu Pendidikan Universitas Negeri Jakarta. 